\title{
FAKTOR-FAKTOR PENENTU GEJALA PENYAKIT KANKER PAYUDARA DENGAN PENDEKATAN JARINGAN SARAF TIRUAN
}

\author{
Gunawan Wibisono, Arief Hermawan \\ Program Studi Magister Teknologi Informasi, Universitas Teknologi Yogyakarta \\ Jl. Siliwangi (Ringroad Utara), Jombor, Sleman, D.I.Yogyakarta \\ e-mail: ${ }^{1)}$ gunawan.wibisono@student.uty.ac.id, ${ }^{2}$ ariefdb@uty.ac.id
}

\begin{abstract}
Abstrak
Kanker Payudara adalah salah satu penyakit yang menjadi momok bagi kaum wanita. Kanker payudara juga menyerang kaum pria akan tetapi kasusnya tidak sebanyak kaum wanita. Dataset klasifikasi kanker payudara Coimbra yang diambil dari UCl Machine Learning, disampaikan bahwa ada 9 atribut yang memengaruhi kondisi seseorang menjadi penderita atau kemungkinan menderita penyakit kanker payudara. Atribut atau faktor tersebut adalah BMI, Glukosa, Insulin, HOMA, Leptin, Adiponectin, Resistin, MCP-1, dan Umur. Tujuan yang akan dicapai dalam penelitian ini adalah menemukan faktor-faktor penentu yang mempengaruhi indikasi penyakit kanker payudara dengan pendekatan Jaringan Saraf Tiruan (JST). Setelah dilakukan simulasi jaringan saraf tiruan dengan 2 lapisan tersembunyi diperoleh hasil bahwa faktor usia menjadi faktor yang memiiki pengaruh terbesar, sedangkan MCP-1 merupakan faktor yang memiliki pengaruh terkecil dalam prediksi penyakit kanker payudara.
\end{abstract}

Kata Kunci: JST, kanker payudara, faktor-faktor penentu

\section{Pendahuluan}

Merujuk data yang dipaparkan Kemenkes per 31 Januari 2019, terdapat angka kanker payudara 42,1 per 100.000 penduduk dengan rata-rata kematian 17 per 100.000 penduduk[1] Penyakit ini merupakan salah satu penyakit yang menjadi momok bagi kaum wanita walaupun tidak menutup kemungkinan pria juga bisa terkena penyakit ini.

Dikatakan menjadi momok bagi kaum wanita, karena penyakit ini menyerang bagian tubuh yang menjadi salah satu ciri khas kaum wanita. Kanker payudara merupakan penyakit yang tidak menular yang cenderung terus meningkat setiap tahunnya, sehingga dapat dikatakan bahwa beban yang harus ditanggung dunia akibat penyakit tersebut semakin meningkat [2].

Ada beberapa faktor yang dapat digunakan untuk memprediksi kehadiran penyakit ini pada kaum wanita. Melalui faktor-faktor tersebut dapat diperkirakan apakah pasien menderita atau kemungkinan menderita. Nilai-nilai dari faktor tersebut diambil dari hasil tes darah pasien. Penelitian oleh [3] menggunakan faktor-faktor kadar Glukosa, Insulin, HOMA, Leptin, Adiponectin, Resistin, MCP-1, Umur dan Berat Masa Tubuh dalam mengklasifikasikan penderita atau kemungkinan menjadi penderita kanker payudara. Dalam penelitian ini ditemukan bahwa sistem dapat memprediksi kehadiran kanker payudara dengan ketepatan $82 \%$. Berdasarkan temuan itu terlihat bahwa sistem belum dapat mengenali dengan sangat baik kehadiran kanker payudara berdasarkan faktor-faktor yang digunakan, diduga dari faktor-faktor yang digunakan terdapat faktor yang tidak memberikan kontribusi atau menjadi penganggu dalam memprediksi kehadiran penyakakit.

Jaringan Syaraf Tiruan (JST) merupakan suatu sistem pemrosesan informasi yang mempunyai karakteristik menyerupai jaringan syaraf biologis. Jaringan Syaraf Tiruan tercipta sebagai suatu generalisasi model matematis dari pemahaman manusia (human cognition)[4]. Salah satu kemampuan jaringan saraf tiruan adalah melakukan prediksi dan reduksi dimensi, yang salah satu aplikasinya adalah mencari faktor-faktor yang dominan menjadi penyebab suatu kondisi [5].

Jaringan saraf tiruan telah terbukti mampu melalukan prediksi dengan baik untuk menyelesaikan berbagai permasalahan. [6] dalam kesimpulannya menyatakan bahwa JST 
dengan algoritma Levenberg Marquardt mampu memberikan akurasi hingga 93,33\% untuk membantu bagian medis untuk mengklasifikasikan jaringan payudara dari pasien ke normal, tumor atau kanker.

[7] menyatakan bahwa Model JST dapat mengenali pola dan mampu mengklasifikasikan status gizi balita ke dalam gizi buruk, gizi kurang, gizi baik dan gizi lebih dengan tingkat kebenaran klasifikasi sebesar $93,85 \%$. Penelitian yang dilakukan oleh [8] menyatakan bahwa jaringan syaraf tiruan yang dikembangkan mampu memprediksi kemampuan siswa dengan ketepatan lebih dari $70 \%$.

JST dalam prosesnya membutuhkan lapisan tersembunyi atau hidden layer, lapisan tersembunyi ini terdiri dari titik titik tersembunyi. Titik titik tersembunyi ini tidak ada dalam di lapisan masukan (input) maupun dalam lapisan keluaran (output), dalam penelitian yang dilakukan oleh [9] menyatakan bahwa seiring meningkatnya jumlah lapisan tersembunyi maka akurasi dapat diperoleh hingga tingkat yang sangat besar tetapi jaringan saraf menjadi kompleks dari sebelumnya.

Kanker payudara adalah keganasan yang berasal dari sel kelenjar, saluran kelenjar dan jaringan penunjang payudara yang ditandai dengan adanya benjolan di payudara, dan pada stadium lanjut terasa sakit. Timbulnya benjolan pada payudara dapat merupakan indikasi adanya tumor atau kanker payudara [10].

Berdasarkan permasalahan yang telah diuraikan dan kemampuan jaringan saraf tiruan maka diperlukan sebuah sistem yang dapat memprediksi dengan baik kehadiran penyakit kanker payudara pada wanita. Penelitian ini bertujuan untuk mencari faktor-faktor yang mempengaruhi kehadiran penyakit kanker payudara pada wanita dengan menggunakan jaringan saraf tiruan. Hasil dari penelitian ini diharapkan dapat memberikan kontribusi pada pengurangan resiko terkena kanker payudara pada wanita

\section{Metode penelitian}

Untuk mencapai tujuan penelitian, dilakukan langkah langkah sebagai berikut.

a. Menyiapkan data pelatihan dan pengujian yang diambil dari dataset kanker payudara Coimbria dari UCI (University of California, Irvine) Machine Learning Repository. Jumlahnya ada 116 data dengan 10 atribut yang diperlihatkan pada tabel 1. Atribut no1 sampai dengan 9 dipergunakan untuk masukan dan atribut no 10 digunakan untuk keluaran. Pembagian data dilakukan melalui operator Split Data yang ada di Rapidminer dengan ketentuan pembagian adalah $70 \%$ untuk data pelatihan dan 30\% data uji. Metode sampling yang digunakan pada operator Split Data adalah Stratified Sampling / sampling terstratifikasi.

Tabel 2.1. Atribut Dalam Dataset

\begin{tabular}{ccc}
\hline No. & Nama Atribut & Keterangan \\
\hline 1 & Age / Umur & Years atau Tahun \\
2 & $\mathrm{BMl} /$ Indeks Massa Tubuh & $\mathrm{Kg} / \mathrm{m}^{2}$ \\
3 & Glucose & $\mathrm{mg} / \mathrm{dl}$ \\
4 & Insulin & $\mu \mathrm{U} / \mathrm{Ml}$ \\
5 & HOMA & $\mathrm{ng} / \mathrm{Ml}$ \\
6 & Leptin & $\mu \mathrm{g} / \mathrm{Ml}$ \\
7 & Adiponectin & $\mathrm{ng} / \mathrm{Ml}$ \\
8 & Resistin & $\mathrm{pg} / \mathrm{dl}$ \\
9 & MCP-1 & $1=\mathrm{N}:$ Kontrol Kesehatan / \\
10 & Classification & belum tentu penderita \\
& & $2=\mathrm{Y}:$ Sudah pasti penderita \\
\hline
\end{tabular}

b. Menyusun operator dalam Rapidminer untuk mensimulasikan JST. Dalam langkah ini peneliti memulai dengan operator untuk mengambil dataset kanker payudara, operator pembagian data, operator JST untuk melatih data yang kemudian diterapkan melalui 
operator penerapan model dengan menggunakan data pengujian, dan dilanjutkan ke dalam operator performansi yang digunakan untuk mengukur akurasi dan AOC (Area Under the Curve). Susunan operator-operator tersebut diperlihatkan pada gambar 1.

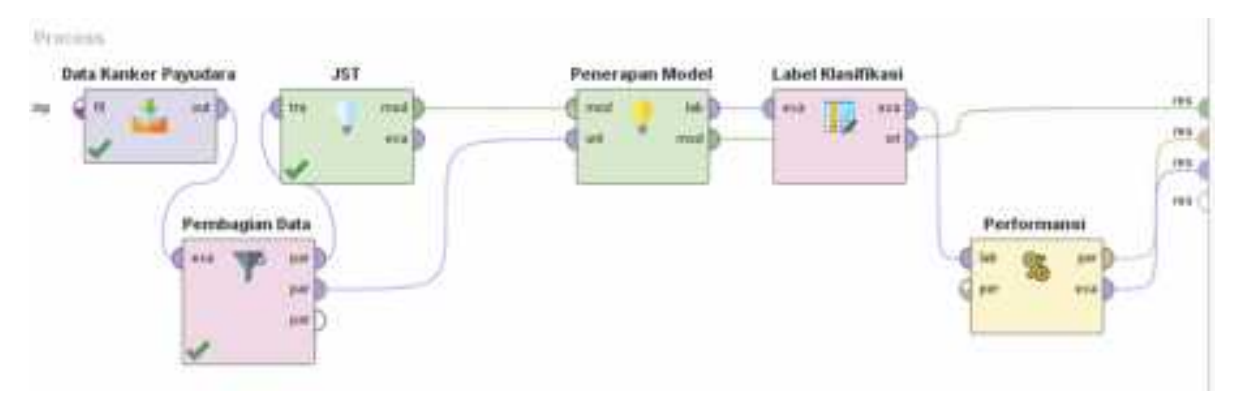

Gambar 2.1. Proses Dalam Rapidminer

c. Pada penelitian ini arsitektur JST yang digunakan terdiri dari 4 lapis, yaitu lapisan input, lapisan tersembunyi pertama, lapisan tersembunyi kedua, dan lapiran output. Arsitektur jaringan saraf tiruan diperlihatkan pada gambar 2

d. Menerapkan model yang sudah didapatkan dari data latih untuk data uji hingga mendapatkan tingkat akurasinya dengan semua atribut yang ada kemudian dicatat hasilnya.

e. Menerapkan model yang sudah didapatkan dari data latih untuk data uji dengan menghilangkan atributnya satu per satu mulai dari atribut nomor 1 pada Tabel 1. dan mencatat akurasinya.

\section{Hasil dan Analisis}

Dataset yang sudah dibagi menjadi 2 bagian yaitu data latih dan data uji, kemudian dimasukan ke dalam operator Neural Net pada Rapidminer. Data latih digunakan untuk menemukan model Neural yang nantinya akan digunakan untuk memodelkan data uji. 
Gambar 2.2. Arsitektur JST untuk Mengklasifikasi Penyakit Kanker Payudara

Dengan menggunakan arsitektur yang diperlihatkan pada gambar 2, JST melakukan iterasi sebanyak 600 kali dengan jumlah lapisan tersembunyi sebanyak 2 lapis dan jumlah sel masing-masing lapisan tersembunyi adalah sebanyak 27 dan 9. Nilai konstanta belajar awal 0.3 dan momentum 0,9, sedangkan error yang diijinkan adalah 1.0E-6.

Setelah dilakukan iterasi sebanyak 600 kali jaringan saraf tiruan selesai melakukan pelatihannya. Pada kondisi tersebut akurasi jaringan saraf tiruan dengan menggunakan data pelatihan sebesar $100 \%$, sedangkan dengan menggunakan data pengujian diperoleh akurasi akurasi sebesar $71,43 \%$ dengan nilai AUC (Area Under the Curve) sebesar 0.813 atau $81,3 \%$ yang masuk dalam rentang nilai Baik. Menurut Sastroasmoro dan Dahlan dalam [11] nilai AUC secara teoritis berada diantara $50 \%$ sampai dengan $100 \%$. Nilai $50 \%$ merupakan nilai AUC terburuk, sementara 100\% merupakan nilai yang terbaik. Intepretasi dari nilai AUC terlihat pada Tabel 2.

Tabel 3.1. Intepretasi Nilai Area Under the Curve (AUC)

\begin{tabular}{cc}
\hline Nilai AUC & Intepretasi \\
\hline$>50-60 \%$ & Sangat Lemah \\
$>60-70 \%$ & Lemah \\
$>70-80 \%$ & Sedang \\
$>80-90 \%$ & Baik \\
$>90-100 \%$ & Sangat Baik \\
\hline
\end{tabular}

Setelah pelatihan dan pengujian dengan menggunakan semua atribut selesai dilakukan, dilakukan kembali pelatihan dan pengujian dengan menggunakan atribut yang dikurangi satu persatu. Data hasil pengujian untuk pengurangan atribut diperlihatkan pada tabel 3. Berdasarkan hasil tersebut terlihat bahwa atribut MCP-1 dianggap tidak terlalu penting karena jika atribut ini dihilangkan nilai akurasi justru naik menjadi 80,00\%. Sedangkan atribut umur menjadi atribut yang penting karena jika atribut Umur dihilangkan maka nilai akurasi mengalami penurunan menjadi $54,29 \%$ dan menjadi nilai terkecil.

Tabel 3.2. Prosentase Akurasi kebenaran JST Setelah Atribut dihilangkan

\begin{tabular}{cc}
\hline Nama Atribut & Prosentase Akurasi jika atribut dihilangkan \\
\hline Age / Umur & $54,29 \%$ \\
Glucose / Glukosa & $68,57 \%$ \\
Resistin & $68,57 \%$ \\
Adiponectin & $71,43 \%$ \\
HOMA & $74,29 \%$ \\
Leptin & $74,29 \%$ \\
BMI / Indeks Massa Tubuh & $74,29 \%$ \\
Insulin & $77,14 \%$ \\
MCP.1 & $80,00 \%$ \\
\hline
\end{tabular}

Selain age atau umur, Glukosa dianggap memberi pengaruh yang besar terhadap penyakit ini karena sel kanker membutuhkan asupan glukosa lebih banyak untuk tumbuh dibanding sel sel sehat lain dalam tubuh, glukosa glukosa ini kemudian diubah menjadi asam laktat oleh sel kanker. Resistin merupakan suatu molekul yang berperan dalam patofisiologi beberapa penyakit seperti penyakit seperti obesitas, diabetes melitus dan aterosklerosis. Diabetes Melitus merupakan penyakit yang salah satu penyebabnya adalah kelebihan kadar gula atau glukosa, secara tidak langsung resistin juga mempengaruhi tingginya kadar gula glukosa.

Dari hasil tersebut diperoleh pengetahuan bahwa glukosa sangat berperan dalam perkembangan penyakit ini, selain umur dari pasien. Seiring dengan bertambahnya umur atau usia tentu metabolisme dalam tubuhpun berkurang akan tetapi umur tidak bisa menjadi patokan 
bahwa dengan umur atau usia yang sudah tua risiko penyakit ini semakin besar, umur atau usia muda dengan kadar glukosa tinggi justru mempunyai risiko lebih besar dari pada umur atau usia tua dengan kadar glukosa normal.

\section{Simpulan}

Berdasarkan proses pelatihan dan pengujian jaringan saraf tiruan untuk mencari faktor penentu gejala penyakit kanker payudara diperoleh hasil bahwa faktor MCP-1 merupakan faktor yang paling tidak berpengaruh terhadap prediksi gejala penyakit kanker payudara. Ketika faktor MCP-1 tidak digunakan justru menambah akurasi data dari $71,43 \%$ menjadi $80 \%$ atau tingkat akurasi naik menjadi $8,57 \%$. Faktor usia menjadi faktor yang sangat berpengaruh karena dengan menghilangkan faktor ini akurasi turun menjadi 54,29\%. Faktor-faktor lain yang berpengaruh selain usia berturut-turut adalah Glukosa, Resistin dan Adiponectin.

\section{Pengakuan dan Penghargaan}

Penelitian ini didukung oleh Program Studi Magister Teknologi Informasi Universitas Teknologi Yogyakarta dan ucapan terima kasih juga kepada Universitas Teknologi Yogyakarta.

\section{References}

[1] B. K. dan P. M. Kementrian Kesehatan RI, "Hari Kanker Sedunia 2019," Kamis, 31 Januari, 2019. [Online]. Available: http://www.depkes.go.id/article/view/19020100003/hari-kankersedunia-2019.html. [Accessed: 11-May-2019].

[2] I. Yulianti, H. S. Santoso, and D. Sutiningsih, "FAKTOR-FAKTOR RISIKO KANKER PAYUDARA (Studi Kasus Pada Rumah Sakit Ken Saras Semarang)," J. Kesehat. Masy., vol. 4, no. 4, pp. 401-409, 2016.

[3] M. Patrício et al., "Using Resistin, glucose, age and BMI to predict the presence of breast cancer," BMC Cancer, vol. 18, no. 1, 2018.

[4] W. M. Dessy and A. Irawan, "Perbandingan Metode Jaringan Syaraf Tiruan Backpropagation Dan Learning Vector Quantization Pada Pengenalan Wajah," J. Komput. dan Inform., vol. 1, no. 1, pp. 45-51, 2012.

[5] A. Hermawan and D. Avianto, "The Implementation of Neural Network on Determining the Determinant Factors Towards Students' Stress Resistance," J. Telecommun. Electron. Comput. Eng., vol. 9, no. 3, pp. 129-133, 2017.

[6] Didi, D. A. Pratiwi, E. Angliati, Fitriani, A. Dayumi, and T. W. Widyaningsih, "Klasifikasi Kanker Payudara Dengan Jaringan Syaraf Tiruan Levenberg Marquadt Berdasarkan Citra Mammography," Semin. Nas. Teknol. Inf., pp. 115-119, 2017.

[7] R. Anggraeni and A. Indrarti, "Klasifikasi Status Gizi Balita Berdasarkan Indeks Antropometri menggunakan Jaringan Saraf Tiruan," SNASTI, pp. 14-18, 2010.

[8] V. O. Oladokun, A. T. Adebanjo, and O. E. Charles-Owaba, "Predicting students' academic performance using artificial neural network: A case study of an engineering course," Pacific J. Sci. Technol., vol. 9, no. 1, pp. 72-79, 2008.

[9] F. S. Panchal and M. Panchal, "Review on Methods of Selecting Number of Hidden Nodes in Artificial Neural Network," Int. J. Comput. Sci. Mob. Comput., vol. 311, no. 11, pp. 455464, 2014.

[10] M. Sihombing and A. N. Sapardin, "Faktor Risiko Tumor Payudara Pada Perempuan Umur 25-65 Tahun Di Lima Kelurahan Kecamatan Bogor Tengah," J. Kesehat. Reproduksi, vol. 5, no. 3, Feb. 2017.

[11] M. Meilani, "Pendekatan indeks antropometri sebagai alat skreening hipertensi pada orang dewasa di daerah urban (Analisis Riskesdas 2007) [Tesis]," Universitas Indonesia, Depok, 2012. 


\section{Daftar Riwayat Hidup}

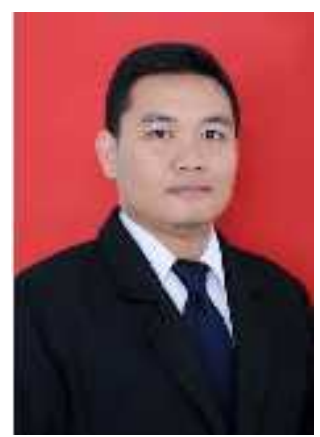

Gunawan Wibisono lahir di Banyumas, 1 Januari 1986. la memperoleh gelar Sarjana dari STIMIK Amikom Purwokerto Jawa Tengah pada 2018. la sedang menempuh program Magister di Magister Teknologi Informasi Universitas Teknologi Yogyakarta. Saat ini ia bekerja di Bagian Sistem Informasi Institut Teknologi Telkom Purwokerto. Minat penelitiannya saat ini adalah IOT, Integrated Recomender System, dan Data Mining.

Alamat Email: gunawan.wibisono@student.uty.ac.id, gunawan@ittelkompwt.ac.id

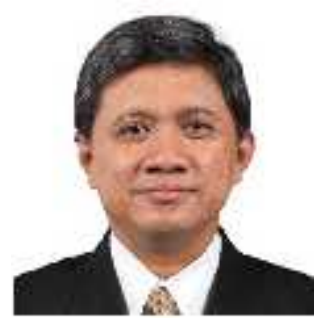

Arief Hermawan lahir di Pekalongan pada tanggal 11 Mei 1970. Gelar Sarjana dan Magister diperoleh dari Universitas Gajah Mada Yogyakarta, sedangkan gelar Doktor diperoleh dari Universitas Negeri Yogyakarta. Bidang minatnya adalah Jaringan Saraf Tiruan.

Alamat Email : ariefdb@uty.ac.id 